\title{
Zasady estetyczne ekspresjonizmu i jeg̊ losy w literaturze rosyjskiej
}

1.

W naukach o sztuce i literaturoznawstwie od dawna przyjęło się twierdzenie, że ekspresjonizm w Rosji nie uformował się jako mniej lub bardziej jednolity system historyczno-literacki. Przyjrzyjmy się jednak faktom. Już w pierwszej dekadzie XX wieku Leonid Andriejew napisał Mur [Стена] i Czerwony śmiech [Красный смех], Życie człowieka [Жизнь Человека] і Anateme [Анатема] utwory, w których ekspresjonizm po raz pierwszy pojawił się jako wyrazisty i znaczący fenomen literacki w prozie i dramaturgii. W latach dziesiątych XX wieku niemal jednocześnie, a chcąc zachować porządek chronologiczny, nieco wcześniej, zanim powstały pierwsze „kultowe” utwory niemieckiej poezji ekspresjonistycznej, narodził się rosyjski futuryzm, który dał światu nie tylko Władimira Majakowskiego, lecz także wielkiego eksperymentatora, ,poetę dla poetów”, Wielimira Chlebnikowa i całą plejadę wielkich twórców poezji (takich jak: Walerij Kamienski, Igor Siewierianin, Aleksiej Kruczonych, Elena Guro, Benedykt Liwszyc). W teoretycznym pojmowaniu ekspresjonizmu jako nowej strategii artystycznej rosyjscy i niemieccy artyści również podążali „równoległym kursem”. Ponadto dzieło Wasyla Kandinskiego O duchowości w sztuce [О духовном в искусстве, 1911] było traktowane na równi z rozprawą Wilhelma Worringera Abstraction und Einfühlung (1908), nazywaną ,,ewangelią ekspresjonizmu”.

Spośród pisarzy rosyjskich, którzy już w pierwszych dziesięcioleciach XX wieku położyli fundamenty pod rozwój ekspresjonizmu, szczególne miejsce zajmują Andriej Bieły i Aleksiej Riemizow.

1. Przekład z języka rosyjskiego na podstawie: Н.Л. Лейдерман, Эстетические принциипь экспрессионизма и его судьба в русской литературе, „Филологический класс” 2008, № 18, s. 12-18. Tekst (oryginał) został opublikowany w recenzowanym czasopiśmie naukowym „Fiłołogicieskij kłas”, afiliowanym przy Państwowym Uniwersytecie Uralskim w Jekaterynburgu, w numerze 18 czasopisma, na stronach 12-18, oraz udostępniony na otwartej licencji Creative Commons Attribution (CC-BY): <https://cyberleninka.ru/article/n/esteticheskie-printsipyekspressionizma-i-ego-sudba-v-russkoy-literature>. 
Riemizow stworzył nowatorską formę narracji, którą można nazwać „groteskowym skazem", jako jeden z pierwszych zaczął posługiwać się poetyką marzeń sennych, często wykorzystywał obrazy folklorystycznego "tamtego świata” i motywy apokryficzne. Wszystkie te innowacje jednocześnie stanowiły dla pisarza narzędzia rozumienia otaczającego świata i sposoby wyrażenia ,,chaograficznego" postrzegania codziennej egzystencji człowieka (powieść Prud ${ }^{2}$ [Прyd], opowiadania Czasy [Чaсы] , Nieujomnyj bubien [Неуёмный бубен] i in.)². Wydaje się, że właśnie na temat utworów Riemizowa zostało powiedziane: „Skrajnie radykalnie obrawszy temat wartości życia, [...] ekspresjonizm zarazem nieustannie balansował na granicy wysokiej tragicznej groteski i farsy, czegoś obnażenie przyziemnego, rubasznego"'. A tymczasem to twierdzenie zostało wyprowadzone z badań nad niemieckojęzycznym (lub szerzej - zachodnioeuropejskim) ekspresjonizmem.

W swoich dociekaniach estetycznych Riemizow nie był odosobniony. W poezji równolegle z nim na folklorystyczno-mitologicznym materiale prowadził poszukiwania artystyczne Wielimir Chlebnikow. W wielu wierszach (Scytyjskie [Скифское], Do Peruna [Перуну], Pian pan [Пен-Пан]) і poematach (Раппа leśna [Лесная дева], I i Je. Opowieść z wieku kamiennego [И и Э. Повесть каменного века], Szaman i Wenera [Венера и Леший]) poeta odwoływał się do mitologii słowiańskiej, a nawet zagłębiał się w przedcywilizacyjne warstwy kultury, wydobywając z nich obrazy i motywy usytuowane w kręgu semantyki mistycznej, które pomimo swojej funkcji tematycznej stanowiły podstawę dla eksperymentów z ,językiem pozarozumowym” (zaumnyj jazyk). (Coś podobnego tworzył także młody Nikołaj Asiejew w cyklach lirycznych Zor [3ор], Letoriej [Леторей], Wiersze sarmackie [Сарматские песни], Powiej wojana [Повей вояна], powstałych w latach 1914-1916).

Rola Andrieja Biełego, jako artysty i jako teoretyka literatury, literaturoznawcy, jak dotąd nie była obiektem należytego rozpoznania w historii ekspresjonizmu. Chociaż sam Andriej Bieły negował futurystyczną teorię ,języka pozarozumowego", a futurystów nazywał „wyrzutkami”, to w istocie jego idee zawarte w wielu pracach poświęconych problemom poetyki symbolizmu położyły podwaliny pod teorię i praktykę ekspresjonizmu. Są to rozważania o fenomenologii kolorów (Swiaszczennyje cwieta [Священные цвета, 1903]), wezwanie do „twórczości słów” (Magija słow [Магия слов], 1910), próby wykazania estetycznego znaczenia dźwiękowej strony języka artystycznego (Głossolalija: poema o zwukie [Глоссолалия: поэма о звуке], 1917). Co się zaś tyczy praktyki artystycznej samego Biełego, to ekspery-

2. W przypadku braku polskiego tłumaczenia utworów rosyjskojęzycznych tytuły zostają podane według zasad polskiej transkrypcji fonetycznej współczesnego alfabetu rosyjskiego - przyp. tłum.

3. М.В. Козьменко, Алексей Ремизов, w: Русская литература на рубеже веков (1890 начало 1920-х годов), t. 2, ИМЛИ РАН, »Наследие«, Москва 2001, s. 345-367.

4. В.М. Толмачев, Экспрессионизм: конеи фаустовского человека, w: Л. Ришар, Энциклопедия экспрессионизма, Республика, Москва 2003, s. 400. 
menty pisarza w Simfonijach [Симфонии] i w powieści Petersburg [Петербура] stały się co najmniej przewrotem rewolucyjnym w poetyce prozy $z$ uwagi na to, że ujawniły nieznane wcześniej zasoby wyrazistości języka prozatorskiego - w jego melodyce, rytmice, budowie kompozycyjnej. „Nie sposób wyobrazić sobie poezji lat 10. i początków lat 20. (jak i prozy początków lat 20.) bez teorii i eksperymentu Biełego" - podsumowuje pracę O wozdiejstwii esteticzeskogo ekspierimienta Andrieja Biełogo (W. Chliebnikow, W. Majakowskij, M. Cwietajewa, B. Pastiernak) [O воздействии »эстетического эксперимента« Андрея Белого (В. Хлебников, В. Маяковский, М. Цветаева, Б. Пастернак)] Wiaczesław Iwanow 5 .

Nie można wykluczyć, że niedocenienie znaczenia ekspresjonizmu w literaturze rosyjskiej lat 1917-1920 wiązało się z bałaganem w koncepcjach teoretycznych. Każda bardziej lub mniej zorganizowana grupa literacka ogłaszała swoją indywidualność (samost'). Stąd pojawiło się wiele manifestów literackich i deklaracji. Nierzadko nie stanowiły one uzasadnienia żadnej konkretnej praktyki twórczej, niektóre z nich były traktowane jako różnorodne i o samoistnej wartości utwory piśmiennictwa nieartystycznego. Jednak przypatrując się bliżej temu chaosowi teoretycznemu, można zauważyć, że wiele deklaracji głosiło bardzo zbieżne idee teoretyczne. Pod tym względem widać wyraźne pokrewieństwo z zasadami estetycznymi i praktykami artystycznymi futurystów (później - LEFowców) i tych, którzy nazywali siebie zaumnikami, imażynistami, niczewokami, fuistami, emocjonalistami, konstruktywistami i właśnie ekspresjonistami - w istocie stanowili oni całe spektrum modernistycznych i awangardowych grup, istniejących w latach 1917-1925.

Większość badań poświęconych niemieckojęzycznemu ekspresjonizmowi wskazuje, że najważniejszym czynnikiem, który spowodował ekspresjonistyczny „wybuch”, była pierwsza wojna światowa - ona podkopała wiarę w humanistyczne wartości, obnażyła ciemną stronę ludzkiej natury itd. Co w takim razie można powiedzieć o Rosji po 1917 roku? Wszechogarniający chaos rewolucji społecznej i z niczym niezrównana okropność bratobójczej wojny ojczyźnianej. Już sama obiektywna rzeczywistość była bardziej irracjonalna niż jakakolwiek ekspresjonistyczna groteska, już sama psychika człowieka, na którego oczach upadły wszystkie dawne symbole wiary, a pojęcie humanizmu stało się przedmiotem wyszydzenia, została poddana najcięższej próbie. Najważniejsze elementy atmosfery duchowej to z jednej strony poczucie katastrofy, przerażenie panoszącym się chaosem, a z drugiej - gwałtowny,

5. Андрей Белый: проблемы творчества (Статьи. Воспоминания. Публикации), сост. С. Лесневский, А. Михайлов, Советский писатель, Москва 1988, s. 366. Na marginesie można wspomnieć także o wpływie Andrieja Riemizowa „,bez którego, za wyjątkiem Borysa Pilniaka, nie obszedł się żaden ze współczesnych młodych rosyjskich prozaików" - zwracała uwagę jeszcze w 1925 r. Marina Cwietajewa (суt. za: М. Цветаева, Об искусстве, Искусство, Москва 1991, s. 368). 
niszczycielski poryw pobudzany pragnieniem odnowy, życiotwórczości w sferze społecznej, w porządku państwowym, a nawet w skali całego świata.

Społeczna i humanistyczna katastrofa, która wstrząsnęła całą Rosją, była bezpośrednim życiowym materiałem skłaniającym do rozmyślań nad irracjonalnością historycznego rozwoju, nad kruchością wszelkich podwalin - od państwowych po rodzinne - nad relatywizmem etycznym, nad ułomnością ludzkiej natury. Jednym słowem, okrutna rzeczywistość rewolucji i wojny ojczyźnianej katalizowała tę fundamentalną problematykę, która zburzyła na przełomie XIX i XX wieku całą epokę kulturową (określaną jako czasy nowożytne [Nowoje wriemia] albo Modernity) i zrodziła modernistyczny typ kultury z jego fundamentalnymi wyobrażeniami - o chaosie jako uniwersalnej zasadzie porządkowania świata, o ontologicznym błędzie w prawach przyrody, gdzie wszystko, co zrodzone i stworzone, niechybnie musi ulec destrukcji, o nieuchronności ludzkiego fatum...

Przy takiej „kondycji świata” powstały wszelkie podstawy do wydźwignięcia ekspresjonizmu na proscenium procesu literackiego. Jednak dopiero w latach dziewięćdziesiątych, kiedy zniesiono cenzurę i umożliwiono dostęp do wielu zakazanych wcześniej utworów, zaczęły pojawiać się prace, w których zwracano uwagę na ekspresjonistyczne tendencje w literaturze rosyjskiej epoki sowieckiej i podejmowano próby określenia jej miejsca w procesie artystycznym lat dwudziestych ${ }^{6}$. Niemniej jednak w nauce o literaturze do tej pory panuje mit, że po październiku rzekomo dominowały tendencje romantyczne?

6. Т.Л. Никольская, О русском экспрессионизме, w: М.О. Чудакова, Тыняновский сборник. Четвертыле Тыняяновские чтения, Зинатне, Рига 1990, s. 173-180; Л.Н. Дарьялова, Русский экспрессионизм в прозе 20-х годов: немецкие истоки, национальное своеобразие, w: Актуальные проблемы и перспективы филологии, КГУ, Калининград 1996; В. Терехина, Бедекер по экспрессионизму, »Арион« 1998, № 1; В. Терехина, Экспрессионизм: русские реалии, »Человек« 2000, № 2; Л.Н. Анпилова, Проза Бориса Пильняка 20-х годов: поэтика художественной целлостности, Диссертация кандидата филологический наук, Екатеринбург 2003; М.М. Голубков, Экспрессионистические тендениии, w: М.М. Голубков, Русская литература XX в.: после раскола, Аспект Пресс, Москва 2001, s. 220-225. Gwoli ścisłości należy dodać, że po raz pierwszy o ekspresjonistycznym nurcie w literaturze rosyjskiej epoki sowieckiej pisał Arkadij Pawłowicz Eliaszewicz w monografii Лиризм, экспрессия, гротеск (О стилевых течениях в литературе соииалистического реализMa), opublikowanej jeszcze w 1975 roku; ekspresjonizmowi zostało poświęconych 8 z 16 rozdziałów (rdz. VI-XIV). Jednak w latach siedemdziesiątych monografia ta nie wywarła znaczącego wpływu na zmianę utwierdzonego w sowieckim literaturoznawstwie wyobrażenia o procesie literackim lat dwudziestych. Niewątpliwe zalety pracy Eliaszewicza umniejsza podążanie za oficjalnymi ustaleniami metodologicznymi, wymagającymi, aby każdą ,dozwoloną” tendencję artystyczną rozpatrywać zgodnie z duchem socrealizmu, a także niejasność zasad teoretycznych.

7. Zob. nр.: История русской советской литературы в 4-х томах, Наука, Москва 1967, t. 1. (1917-1929), s. 18-32; История русской советской литературы (1917-1941), ред. И.А. Метченко, С.М. Петров, Просвещение, Москва 1975, s. 29 i kolejne; В.В. Мусатов, История русской литературы первой половины ХХ века (советский период), Академия, Москва 2001, s. 26-34. 
A co rzeczywiście miało miejsce?

Już w pierwszych dniach października futuryści zajęli wiodącą pozycję w poezji, przemianowując swoje ugrupowanie na LEF (Lewyj front iskusstw). Upojenie żywiołem, feeria dźwięków, swobodna gra materii słowa, deformacje planu wyrażania - wszystkie te cechy poetyki futurystycznej przedstawiano za pomocą takich „form czasu”, jakie najbardziej wpisywały się w ducha rewolucji.

W prozie pierwszych lat października przodowali Jewgienij Zamiatin i Borys Pilniak (zdaje się, że nieprzypadkowo pierwszy z nich był członkiem zarządu leningradzkiego oddziału Związku Pisarzy, drugi - moskiewskiego). Dominanta ekspresjonistyczna w twórczości Borysa Pilniaka była oczywista. Stosunek Zamiatina do ekspresjonizmu był bardziej skomplikowany: twierdząc, że najbardziej nowoczesnym nurtem artystycznym jest neorealizm, pisarz, kiedy charakteryzował poetykę neorealizmu, wymieniał te środki artystyczne, które od dawna były „popisowymi” narzędziami ekspresjonizmu (groteska, koszmarność, brzydota, ironia). Jednak cykl opowiadań, napisanych przez Zamiatina w latach 1918-1922 (Łowca ludzi [Ловец человеков], Smok [Дракон], Jaskinia [Пещера], Mamaj [Мамай], można uznać za klasykę ekspresjonizmu. Z kolei w powieści-antyutopii My [Мы, 1921] pisarz stworzył monumentalno-groteskowy obraz ustroju państwa, funkcjonującego według racjonalno-bezdusznych praw, czyniących z człowieka bezosobowy „numer” - mechaniczną istotę myślącą wedle weryfikowalnych wzorów.

W prozie Pilniaka i Zamiatina początków lat dwudziestych XX wieku można wyznaczyć dwie linie rozwoju rosyjskiego ekspresjonizmu. Pierwsza z nich zorientowana jest na tradycję folklorystyczną, mającą swe korzenie w archaicznej poetyce tradycyjnego ,tamtego świata”. Druga linia koncentruje się na tradycji charakterystycznej bardziej dla europejkkiego ekspresjonizmu - racjonalistycznej umowności, eksperymentalności sytuacji, „maskowości” postaci (biorącej swe źródło w Listach ciemnych mężów [Epistolae obscurorum virorum] i Pochwale głupoty [Morias egchomion id est Stultitiae laus] Erazma z Rotterdamu, Podróżach Guliwera [Gulliver's Travels] Jonathana Swifta, powiastkach filozoficznych Woltera). Pierwszą linię można nazwać karnawałową, a drugą - maskaradową ${ }^{8}$. Nie wdając się $\mathrm{w}$ analizowanie historii każdej z linii, można w przybliżeniu wyznaczyć ich granice w poezji. Początek pierwszej z linii - Spowiedź chuligana [Исповедь хулигана, 1920] Siergieja Jesienina (maska chuligana, epatowanie rozpustą i upadkiem moralnym,

8. Taka „bliźniaczość” terminów, zaproponowana niegdyś przez Michaiła Michajłowicza Bachtina dla dyferencjacji dwóch typów świadomości kulturowej - narodnoj, burzliwej i świeckiej, świadomie tworzonej, jest dobrą nazwą dla dyferencjacji dwóch linii w rosyjskim ekspresjonizmie. 
demonstracyjne zestawienie „czystej” i „nieczystej praprzyczyny”), i zakończenie - Pogorzelizna [Понорельщина] Nikołaja Klujewa (straszne obrazy zezwierzęcenia zamieniającego dotychczasowy wiejski porządek). Druga linia - to opowiadania i nowele Zygmunta Krzyżanowskiego (Klub Morderców Liter [Клуб убийи, букв], W zraczkie [В зрачке], Stranstwujuszczeje „stranпо” [Странствующее «странно»] i in.). Do tej grupy zaliczają się również antyutopie Michaiła Bułhakowa Fatalne jaja [Роковые яйца] і Psie serce [Собачье сердие]. A także Podporucznik Kiże [Поручник Киже] і Woskowa persona [Восковая персона] Jurija Tynianowa, opowiadania i nowele młodego Wieniamina Kawierina: Chronika goroda Lejpciga za 18.. god [Хроника города Лейпцига за 18.. год], Piatyj strannik [Пятый странник], Весzka [Бочка], Bolszaja igra [Большая игра] $)^{10}$.

Linie „karnawałowa” i „maskaradowa” zgodnie współistniały, ściśle do siebie przylegały, a czasem przecinały się wzajemnie. W twórczości Pilniaka i Zamiatina można wyróżnić utwory skłaniające się ku jednemu albo drugiemu biegunowi. Takie samo współistnienie dwóch odgałęzień zauważa się w prozie młodego Ilji Erenburga. W powieści Niezwykłe przygody Julia Jurenity i jego uczniów [Необычайные похождения Хулио Хуренито и его учеников, 1922], będącej parodią gatunku awanturniczo-przygodowego, przedstawiony został obraz porządku świata niewspółgrający z kryteriami intelektualnymi, których nosicielem jest pseudoawanturnik Julio Jurenito (paradoksalny obraz rozumnego i nieszczęsnego tułacza). Z kolei w powieści Burzliwe życie Lejzorka Rojtszwańca [Бурная жизнь Лазика Ройтшванеца, 1928] pisarz obnażył absurdalność współczesnego porządku świata w świetle ludowej mądrości, którą prezentuje w formie paradoksalnych przypowieści maleńki krawiec z żydowskiego miasteczka (jego prototyp - Herszele z Ostropola, legendarny humorysta i mędrzec, główny bohater folkloru rosyjskich Żydów).

Rosyjski ekspresjonizm lat dwudziestych nie tylko aktywnie wykorzystywał formy wypracowane przez swoich poprzedników, ale także je zintensyfikował $\mathrm{i}$ istotnie wzbogacił. $\mathrm{W}$ poezji przejawiało się to $\mathrm{w}$ znacznie częstszym wykorzystywaniu ,popisowych” chwytów ekspresjonistycznych - dźwiękonaśladownictwa, paronomazji, w tworzeniu obrazów poprzez podział słowa na morfemy (eksperymenty Mariny Cwietajewej i Ilji Sielwinskiego), w odkryciu „odwrotnych tropów”,

9. Zob. B.A. Сухов, Сергей Есенин и имажинизм. Диссертация кандидата филологических наук, Москва 1997.

10. Tę linię J.B. Skorospiełowa rozpatruje jako jeden z nurtów ideowo-stylistycznych w prozie lat dwudziestych, w którym dominował szczególny typ umowności („hoffmanniana”) [termin pochodzi od nazwiska Ernsta Theodora Amadeusa Hoffmanna, niemieckiego poety i pisarza epoki romantyzmu, prekursora fantastyki grozy - uzup. tłum.]. Zob. Е.Б. Скороспелова, Идейно-ститевые течения в русской советской прозе первой половины 20-х годов, Изд-во Московского ун-та, Москва 1979, s. 49-77. 
w których żywe upodabnia się do martwego, naturalne - do sztucznego (w rodzaju Asiejewskiego „stalowego słowika”).

Wyjątkowo dużo innowacji poczyniono w prozie. Tutaj wiodącą zasadą modelowania świata przedstawionego jest fantasmagoryczność - groteskowo-hiperbolistyczna deformacja, szokująca straszliwą irracjonalnością, dochodzącą do absurdu ${ }^{11}$. Jeśli w prozie ekspresjonistycznej lat dziesiątych XX wieku fantasmagoria najczęściej motywowana była poprzez zaburzenia psychiczne podmiotu poznania (Mały bies [Мелкий беc] Fiodora Sołoguba, Petersburg [Перетбург] Andrieja Biełego), to w latach dwudziestych fantasmagoryczność czasem motywowana jest pewnymi umowno-zabawowymi założeniami: zabiegami magicznymi, w wyniku których zachodzą czarodziejskie przemiany (np. opowiadania Krzyżanowskiego Stranstwujuszczeje „stranno" [Странствующее «странно»] і W zraczkie [В зрачке], nowela Kawierina Chronika goroda Lejpciga za 18.. god [Хроника города Лейпцига за 18.. год]), a częściej - założeniami, opartymi na ironicznym wykorzystaniu modnego zainteresowania utopiami naukowymi i projektami (np. Psie serce [Cобачъe серди,] і Fatalne јаја [Роковые яйиа] Michaiła Bułhakowa). Takie założenia tworzą „stricte laboratoryjne warunki” do przeprowadzenia określonego eksperymentu moralnego czy psychologicznego.

Najczęściej jednak fantasmagoryczność przejawia się w ówczesnej rzeczywistości i obowiązujących w niej normach. U Zamiatina taki jest obraz zdziczenia mieszkańców zamarzniętego miasta, ich przemiana w „smoko-ludzi” (opowiadania Jaskinia [Пещера] i Smok [Дракон]). U Olgi Forsz - codzienność wygłodzonych literatów zamieszkujących piotrogrodzki dom (powieść Sumasszedszyj korabl' [Сумасшедиий корабль]). A w noweli Pantielejmona Romanowa Prawo na żyzn', ili probliema bezpartijnosti [Право на жизнь, или проблема беспартийности] - historia bezpartyjnego literata Leonida Siergiejewicza Ostankina, którego doprowadziły do samobójstwa stawiane mu wymogi bycia osobą polityczną.

Ekspresjonistyczni prozaicy wypracowali rozbudowaną poetykę, obnażającą fantasmagoryczny charakter otaczającej rzeczywistości i jednocześnie przekazującą poczucie irracjonalności, którym szokowana jest świadomość człowieka będącego wewnątrz tego świata. Mamy tu całą kaskadę chwytów stworzonych przez Zyg-

11. Należy podkreślić, że groteska, w odróżnieniu od innych sposobów deformacji (na przykład hiperbolizacji czy litoty) zawsze niesie ze sobą semantykę okropności, straszliwości, tego, czego w życiu się nie spotyka. „Świat groteski romantycznej to - w mniejszym lub większym stopniu świat straszny i obcy człowiekowi. Wszystkie nawyki, cała zwykłość, codzienność, przyzwyczajenia, wszystko ogólnie uznane - nagle oto staje się niedorzeczne, wątpliwe, obce i wrogie. Świat własny zmienia się nagle w świat obcy. Ze spraw zwykłych i niestrasznych nagle wyłaniają się straszne" - pisał M.M. Bachtin (M.M. Bachtin, Twórczość Franciszka Rabelais'go a kultura ludowa średniowiecza i renesansu, przeł. Anna i Andrzej Goreniowie, Wydawnictwo Literackie, Kraków 1975, s. 102.). Charakterystyka ta doskonale określa istotę groteskowej fantasmagorii w ekspresjonizmie. 
munta Krzyżanowskiego w nowelach fantastycznych: „obrazy myślowe” (obrazy samotności, rozmów, obrazy lekkich i ciężkich snów, szczelin i „szczelinowej etyki”), personifikacja form czasu i przestrzeni, komórek krwi i tkanek nerwowych (w opowiadaniu Stranstwujuszczeje „stranno” [Странствующее «странно»] - „Zwinne i tycie sekundy”"12, „młody leukocytnik”13, „odrośla neuronów”14), materializacja całych idiomów (w tymże opowiadaniu jest mikronowela o królu, który „grywał w ludzi”, a później sam zamienił się w kartę do gry $)^{15}$. Mamy tu również błyskotliwe rozwijanie anegdoty w absurdalne kolizje fabularne (Podporucznik Kiże [Поручник Киже] Jurija Tynianowa), styl językowy przedstawiający wolapik złożony z sowieckiego oficjalnego nowojazu i skazowej mowy prostego ludu (Arystokratka [Аристократка], Łaźnia [В бане] i inne opowiadania Michaiła Zoszczenki). Poza tym poetyka narracyjna demonstracyjnie ulega subiektywizacji - narrację zastępuje fiksacja, elementem narracyjnym plątaniny wydarzeń staje się tak zwany styl telegraficzny, fragmentaryczność artystycznej rzeczywistości porządkują nieokreślone związki asocjacyjne i motywy kompozycyjne. Tradycyjne chwyty modernistyczne w ekspresjonizmie przybierają skrajny stopień intensywności: zmaterializowane metafory rozrastają się w całe fabuły, synekdochy autonomizują się na tyle, że „nabierają zastraszającej samodzielności” (В.Н. Пестова), czasami jeden epitet przechodzi w integralny obraz - dominantę emocjonalną całego świata przedstawionego. Wiktor Szkłowski ironicznie zwrócił uwagę na tę kwestię, pisząc:

Opis Drezna wymagałby więcej pracy. Jest jednak sposób, chętnie stosowany w nowej literaturze rosyjskiej. Bierzemy jakiś szczegół Drezna, na przykład to, że jeżdżą po nim czyściutkie samochody, obite od wewnątrz szarym materiałem w paski. Dalej wszystko jest tak proste, jak dla dźwigu podniesienie jednej tony. Następnie trzeba zapewnić czytelnika, że całe Drezno jest szare i w paski, że Łaba to pasek na szarym tle, że domy są szare, że Madonna Sykstyńska jest szara i w paski. Nieważne, czy to prawda, ważne, że jest to przekonujące i w dobrym guście. Szarym w paski ${ }^{16}$.

12. »юркие и крохотные секунды«, С. Кржижановский, Странствующее »странно«, w: С. Кржижановский, Сказки для вундеркиндов, Советский писатель, Москва 1991, s. 96.

13. »молодой лейкоцитняк«, С. Кржижановский, Странствующее..., s. 112.

14. »отростки нейронов«, С. Кржижановский, Странствующее..., s. 108.

15. Analizę sposobów, którymi posługiwał się Zygmunt Krzyżanowski, tworząc swe fantastyczne światy, odnaleźć można w: Й. Ван-Баак, Мир по Кржижановскому, „Russian Literature” 1999, vol. XLV, s. 361-371. Zob. także: Н.Ю. Буровцева, Проза С. Кржижановского: проблему поэтики. Диссертация кандидата филологических наук, Москва 1998; Е.В. Моисеева, Художественный мир прозы С. Кржижановского. Диссертация кандидата филологических наук, Екатеринбург 2002.

16. W. Szkłowski, Zoo. Listy nie o miłości albo Trzecia Heloiza, w: W. Szkłowski, Jeszcze nie wszystko skończone..., przeł. Aleksandra Berkieta, Jolanta Skrunda, Wydawnictwo Akademickie SEDNO, Warszawa 2016, s. 398. 
Poetyka uformowana w rosyjskim ekspresjonizmie służy jako „,materiał budulcowy" jednego z najbardziej skrajnych wariantów modernistycznej koncepcji świata - świata jako absolutnego chaosu. Jednak sam „chaograficzny” model świata nie ulega rozpadowi, a jedynie jego całościowość opiera się na zupełnie innych podstawach niż w systemach klasycznych i różni się od pokrewnych systemów modernistycznych (w szczególności od symbolizmu). Dominantą ekspresjonistycznej całościowości jest „antykosmograficzność", to znaczy budowanie modelu świata na podstawach absolutnie przeciwstawnych kosmograficzności: na zestawianiu niepasujących do siebie elementów, na dialogicznym połączeniu wzniosłości z brutalnością i prostactwem, na zburzeniu związków przyczynowych, na wprowadzeniu niezwykłości i alogizmu (a dokładniej - nie nielogizmu a antylogizmu) w konstruktywną i motywacyjną zasadę. W lapidarnej formie strategia ekspresjonistyczna wyrażona została słowami Wielimira Chlebnikowa: „Moj otwleczonnyj strogij rassudok / Jest' korien’ iz Niet-jedinicy"17. Taki oto jest modus rzeczywistości, w którym w maksymalnym zaostrzeniu przejawia się estetyczny stosunek ekspresjonistycznego artysty wobec społecznej, egzystencjalnej, historycznej i każdej innej realności.

Ekspresjonistyczny model świata to antyświat, ale jego wewnętrzna jedność pozostaje motywowana, dlatego mówi się o jego pełnej wirtualności. Tutaj możliwe jest istnienie smoko-ludzi i ludzi-marionetek, przemiana żywego człowieka w statuetkę (Piatyj strannik [Пятый странник] i Chronika goroda Lejpciga za 18. god [Хроника города Лейпиига за 18.. год], a nawet pełna dysocjacja człowieka (straszny obraz rozkładania na części składowe inwalidy pierwszej wojny światowej - Johanna Protezy, bohatera wiersza Aleksieja Kruczonycha) ${ }^{18}$. Tutaj budynek banku w stolicy okazuje się tajemniczym zamkiem okropności (Aleksandr Grin Szczurołap [Крысолов]), a blok w Pitrze, zamieszkiwany przez wygłodniałych literatów, przemienia się w obłąkany statek (powieść Olgi Forsz). Tutaj „umniejszony człowiek" może błądzić w odroślach neuronów mózgu i wzniecać bunt czerwonych ciałek krwi (Zygmunt Krzyżanowski Stranstwujuszczeje „stranno” [Странствующее «странно»]). Tutaj biurokratyczny koszmar staje się motorem napędzającym akcję (Labirynt [Лабиринm] Pantelejmona Romanowa, Diaboliada [Дьяволиада] М. Bułhakowa), a niezamierzona krzywda, jakiej doznał lumpen-hegemon w dni rewolucji - podstawą całego szeregu roszczeń o specjalne ulgi socjalne (M. Zoszczenko, Żertwa riewoluciji [Жертва революции]).

17 „Мой отвлеченный строгий рассудок / Есть корень из Нет-единицы”, w: В. Хлебников, Есть запах ивветов медуниць ш: Собрание произведений Велимира Хлебникова, ред. Ю. Тынянов, Н. Степанов, t. 5., Издательство писателей в Ленинграде, Ленинград 1933, s. 93.

18. Zob. A. Кручоных, 1914-24 гг., »Леф« 1925, № 3(7), s. 30-32. Opatrzono podtytułem: Wolny przekład z niemieckiego. 
Ekspresjonistyczne antyświaty mają swoją gatunkową dominantę (metagatunek), którą jest fantasmagoryczna zasada modelowania. Łączy ona całą grupę gatunków, a główne miejsce zajmują w niej antyutopie i tragikomedie, pod wpływem których odnawiają się i asymilują tradycyjne gatunki (bajki magiczne, objawienia, przypowieści), natomiast sny i koszmary stają się samodzielnymi gatunkami. $\mathrm{W}$ tendencji ekspresjonistycznej wyodrębniła się także własna dominanta stylistyczna - groteska w najróżniejszych jej odmianach. Wszystko to daje podstawy, aby twierdzić, że w Rosji w pierwszych latach po październiku ekspresjonizm sformował się w całościowy kierunek literacki, to znaczy urósł do rangi wielkiego systemu historyczno-literackiego, nosiciela określonej artystycznej filozofii. Właśnie w tym znaczeniu ekspresjonizm został strategią artystyczną, która dawała najbardziej adekwatną możliwość zrozumienia i wyrażenia zarówno „kondycji świata” w czasie rewolucji i wojny ojczyźnianej, jak i „kondycji ducha” ludzi wmieszanych w wszechpanujący chaos i dostrzegających, że rozpoczęty proces budowania „nowego świata” rodzi nowy absurd.

W Rosji w pierwszym porewolucyjnym dziesięcioleciu ekspresjonizm stał się dominującą tendencją procesu twórczego - objął wszystkie rodzaje sztuki, z nim związane są najbardziej znaczące osiągnięcia artystyczne tamtych czasów. Wymienić można między innymi wybitne płótna Kuźmy Pietrowa-Wodkina, Marca Chagalla, Pawła Fiłonowa. Są to filmy Pancernik Potiomkin [Броненосеu, Потемкин] Siergieja Eisensteina i Matka [Mamb] Wsiewołoda Pudowkina, przedstawienia teatralne Wsiewołoda Meyerholda i Aleksandra Tairowa, stanowiące klasykę światowego ekspresjonizmu, szkołę dla wielu przyszłych pokoleń kinematografów i reżyserów teatralnych.

3.

W latach dwudziestych ekspresjonizm rozwijał się w sąsiedztwie i rywalizacji z innymi prądami literackimi - romantycznym, realistycznym i formującym się socrealizmem. Nie dziwi zatem fakt, że zachodziły między nimi wzajemne interakcje.

Z romantyzmem ekspresjonizm pozostawał związany pod względem genetycznym - odziedziczył po nim zasadę konfrontacji z rzeczywistością, subiektywną dominantę wizji artystycznej. Tradycja realistyczna w literaturze rosyjskiej była na tyle silna, że jej wpływ nie ominął żadnego prądu artystycznego powstałego w XX wieku. Pomimo zadziorności i chęci epatowania odbiorcy rosyjski ekspresjonizm okazał się podatny na kilka najważniejszych zasad realizmu. Przede wszystkim na zasadę motywacji psychologicznej postaci - nawet tych najbardziej fantasmagorycznych. A to pokazuje, że typizacja jako najważniejsza zasada stra- 
tegii realistycznej w mniejszym bądź większym stopniu wpływa na charakter generalizacji (zasady artystycznego uogólnienia) w ekspresjonizmie - obraz ekspresjonistyczny, stając się skrajnie ogólnym wyrażeniem estetycznego stosunku do rzeczywistości, jednocześnie odkrywa obiektywny sens ocenianych zjawisk. Można wskazać odkryte dzięki strategii ekspresjonistycznej ludzkie typy, które stały się ,kultowymi obrazami” nie tylko swoich czasów, lecz także całej epoki, rozpoczętej po październiku: lumpen-hegemon (Szarikow z Psiego serca [Собачье сердце]), skazowy opowiadacz z opowiadań Zoszczenki, Piotr Prysypkin z komedii Majakowskiego Pluskwa [Клоп], biurokrata nowej sowieckiej formacji, demagog i urzędas (Pobiedonosikow i Optimistenko z Łaźni [В бане] Majakowskiego, Kalsonier z Diaboliady [Дьяволиада] Bułhakowa), uniżony inteligent (pisarz Ostankin z noweli Romanowa Prawo na żyzn', ili probliema bezpartijnosti [Право на жизнь, или Проблема безпартийности]), aktywny reżimowy konformista (Guliaczkin $\mathrm{z}$ komedii Nikołaja Erdmana Mandat [Мандат]), nowa funkcja tradycyjnego bohatera rosyjskiej klasyki - małego człowieka (człowiek-numer z powieści Zamiatina $M y[M b l])$, ,umniejszony człowiek” z opowiadania Krzyżanowskiego W zraczkie [B зрачкe], prześladowany żądaniami, by zostać ofiarą w imię obcych, błahych interesów, nieszkodliwy Podsiekalnikow z komedii Erdmana Samobójca [Самоубийа]. W ekspresjonistycznej optyce w istocie jedni bohaterowie zostali przedstawieni jako złowieszcza siła, inni jako żałosne istoty czy postaci tragifarsy, a jeszcze inni - jako tragiczne ofiary.

Niektórzy artyści tworzyli groteskowy obraz świadomości i świata zbaczającego z moralnej drogi poprzez połączenie realistycznego naśladownictwa życia z ekspresjonistycznym absurdem. Tendencja ta najwyraźniej zarysowuje się w tragikomediach Erdmana (Mandat [Мандат], Samobójca [Самоубийца]). Wyzywająca kontaminacja wyjątkowo ekspresjonistycznego widzenia świata (fiksacja irracjonalnych zjawisk czasu, ,chaotyczna” narracja) z niemal dokumentalnymi epizodami, z opisem łatwo rozpoznawalnych rzeczywistych osób, twórców kultury rosyjskiej, jest charakterystyczna dla takich niebanalnych utworów, jak: Zoo. Listy nie o miłości albo Trzecia Heloiza [Zoo, или Письма не о тюбви, 1923] Wiktora Szkłowskiego, Sumasszedszyj korabl' [Сумасшедший корабль, 1930] Olgi Forsz.

Wpływ ekspresjonizmu na romantyczny obraz świata przejawiał się także przede wszystkim w zhiperbolizowanych sposobach wyrażania. W „poematach w prozie” realia otaczającego świata są wyraźnie zabarwione i metaforycznie odnoszą się do astralnych i sakralnych zjawisk i znaków. Tak oto na przykład opisywany jest nieboskłon: „O brzasku, gdy pomiędzy dwoma garbami Wielkiego Czimganu zalśni niebo szmaragdem i zamigocą na nim ledwo dostrzegalne różne błyski, 
góra ciemnieje i ogromna, granatowa zawisa nad jedwabistą ciszą doliny”" ; „Zorza, rozpuściwszy płomienne skrzydła, wzleciała nad ciemnym stepem”" ${ }^{20}$ „Cienki róg księżyca pławił swoje strzały w czarnej wodzie Teterewu"21. W istocie wszystkie te formalne innowacje były organicznym przedłużeniem tradycyjnych, szczególnych cech poetyki romantyzmu, ale naraz zyskały one wyjątkową intensywność, która semantycznie odpowiada skrajnie zarysowującemu się przeciwstawieniu biegunów binarnego romantycznego świata - bieguna ideału i bieguna rzeczywistości.

W pierwszym popaździernikowym dziesięcioleciu to właśnie ekspresjonizm stał się tą artystyczną intencją, która zarażała wszystkie prądy artystyczne i tendencje tamtych lat. Wynika to $z$ faktu, że w nieustannym sporze między przedstawianiem a wyrażaniem szala przechylała się ku wyrażaniu. Nieokiełznana i wzburzona rzeczywistość wzbudzała ostrą emocjonalną reakcję, która mogła z początku być, bez „dystansu czasowego”, jedynie subiektywna.

\author{
Tłumaczyła Agnieszka Ścibior \\ Uniwersytet Jagielloński $w$ Krakowie \\ (iD https://orcid.org/0000-0002-8093-5695
}

19. Boris Ławrieniew, Gwiaździsty blask, w: Boris Ławrieniew, Czterdziesty pierwszy i inne opowiadania, przeł. Maria Wisłowska, Wydawnictwo Ministerstwa Obrony Narodowej, Warszawa 1960, s. 37.

20. »Заря, распустив сияющие крылья, взлетела над темной степью...«, Артем Веселый, Гуляй Волга, Слово Тюмени, Тюмень 1993, s. 7.

21. Izaak Babel, Syn rabbiego, w: Izaak Babel, Historia jednego konia, przeł. Jerzy Pomianowski, Czytelnik, Warszawa 1988, s. 183. 